\title{
CharaCterising PRICE FIXING: A JOURNEY THROUgh THE LOOKING GLASS WITH $A N S A C$
}

\author{
Kasturi Moodaliyar \\ Oliver Schreiner School of Law, University of Witwatersrand, School of Law \\ Keith Weeks \\ Enforcement and Exemptions Division, South African Competition Commission
}

\begin{abstract}
In February 2005 the Supreme Court of Appeal of South Africa ruled that in deciding whether firms have contravened section 4(1)(b) of the Competition Act 89 of 1998, as amended, by engaging in, for example, 'per se' illegal price fixing, the Competition Tribunal must admit evidence relating to the nature, purpose and effect of the horizontal agreement or practice in question. This article examines the economic and legal rationale, as well as the implications, for allowing an appropriate characterisation of conduct to determine whether such conduct falls within the per se prohibition. Firstly, we comment on the rationale behind the per se rule as a standard for the adjudication of certain types of conduct. We analyse a number of cases in the United States, which, post 1979, revolutionised the approach to the strict per se rule. Secondly, we examine how the per se standard is reflected in the particular structure found in section 4(1) of the Competition Act and evaluate whether it makes for a sufficiently robust application of the per se rule. Thirdly, the content of the Supreme Court decision regarding characterisation is critically examined with a view to assessing whether such characterisation is consistent with the policy objective of achieving maximum deterrence of hard core cartel behaviour like price fixing and market division. Finally, we explore and suggest (in the absence of a Tribunal decision) a possible framework, based on decision theory, for determining a method of characterisation that is consistent with the robust application of the per se standard and is in line with the Supreme Court ruling.
\end{abstract}

Abstract

JEL L41

\section{1}

\section{Introduction}

It is well understood by economic thinkers and policy makers that agreements between competitors that prevent or restrict competition can do serious harm to the ability of the market mechanism to deliver the benefits of productive enterprise to consumers. Agreements by cartels to divide markets, limit output or fix selling prices constitute among the most egregious of these restrictions.

Public policy toward cartels and cartel-like behavior is manifest in the competition laws of the greater majority of those countries that have allowed some form of market system to underlie their economies. In enacting laws against cartels these countries have accepted the conventional economic wisdom that, as a general rule, agreements among competitors to fix prices or divide markets are likely to have such a deleterious effect on competition that it is of great importance that laws preventing such conduct be applied effectively and expeditiously.

South Africa is no different in this respect. In addressing cartel behaviour Section (s) 4(1)(b)(i)-(iii) of the South African Competition Act 89 of 1998, as amended, ("the Act") contains provisions prohibiting the restrictive horizontal practices of price fixing, dividing markets and collusive tendering. However, the Act is in 
the early stages of its implementation and the jurisprudence has not yet settled on a definitive approach.

This state of affairs is most evident in the recent ruling of the Supreme Court of Appeal ("the SCA") of South Africa in the matter of the American Natural Soda Ash Corporation (Ansac) versus the Competition Commission ('the Commission'), the Botswana Soda Ash Company (Botash) and others ${ }^{1}$. The Ansac litigation dates back to late 1999 when Botash filed a complaint with the Commission alleging that Ansac was operating in South Africa in contravention of inter alia s 4(1)(b)(i) and s 4(1)(b)(ii) of the Competition Act. In other words, Botash alleged that Ansac had engaged in price fixing and division of markets.

The Commission finalised its investigation in 2000 and referred the complaint to the Competition Tribunal ("the Tribunal") for adjudication. At the pre-hearing stage the Tribunal asked the parties to present their arguments on the interpretation of s 4(1)(b) and then attempted to determine whether s 4(1)(b) allowed for an efficiency defence ${ }^{2}$. In 2001 the Tribunal made further determinations on $\mathrm{s}$ 3(1) and Botash's locus standi in this case. The Tribunal found against Ansac, who subsequently appealed to the Competition Appeal Court (CAC). The CAC agreed with the Tribunal's decision and Ansac lost its appeal. However, it did not end there as Ansac then brought its case to the SCA, whose ruling this article is primarily concerned with.

This article examines the economic and legal rationale, as well as the implications, for allowing an appropriate characterisation of conduct to determine whether such conduct falls within the per se prohibition. Firstly, we comment on the rationale behind the per se rule as a standard for the adjudication of certain types of conduct. We analyse a number of cases in the United States, which, post 1979, revolutionised the approach to the strict per se rule. Secondly, we examine how the per se standard is reflected in the particular structure found in s 4(1) of the Competition Act and evaluate whether it makes for a sufficiently robust application of the per se rule. Thirdly, the content of the Supreme Court decision regarding characterisation is critically examined with a view to assessing whether such characterisation is consistent with the policy objective of achieving maximum deterrence of hard core cartel behaviour like price fixing and market division. Finally, we explore and suggest (in the absence of a Tribunal decision) a possible framework, based on decision theory, for determining a method of characterisation that is consistent with the robust application of the per se standard and is in line with the SCA ruling.

2

\section{Distinction between cartels and joint ventures}

Cartel $^{3}$ agreements are usually entered into by two or more competing firms, who agree to coordinate their business in a conspiracy primarily to lessen competition between them. Cartel agreements include price fixing, dividing markets and collusive tendering. Cartels "remove producers' incentives to perform at the highest level possible, thus undermining the goal of producing robust and competitive businesses, and they keep prices higher and performance lower, thus harming buyers" (Fox, 2002: 800). They are thus said to be 'naked' agreements as there are no pro-competitive reasons arising from these types of agreements (Hovenkamp, 1999: 144). Firms who are party to the naked agreement should be subject to the per se rule, because the arrangement would "always or almost always tend to restrict competition and reduce output." 4

There are other types of collaborative arrangements between competitors, which are created for legitimate reasons. Joint ventures, for example, are usually entered into to achieve economies of scale, to allow firms to produce or supply products at lower cost, or to enable them to bring to market a product that they would not be able to do individually. Perhaps the most important feature that distinguishes cartels from other joint ventures is the absence of a potentially efficiency-enhancing economic integration among the participants. ${ }^{5}$

However, even though joint ventures may have the intention to promote efficiency, they may also lessen competition among the joint venture 
partners. ${ }^{6}$ "If the ventures dominate a market they may attempt to earn monopoly profits by reducing output and raising price, dividing markets, or by refusing to compete in innovation or some avenue other than price. They may also try to protect their own competitive positions by excluding price cutters or firms that are more innovative than themselves" (Hovenkamp, 1999: 198). In such cases, joint ventures may be prohibited per se if they involve price fixing, or alternatively, prohibited under a rule of reason analysis if they are otherwise anticompetitive. However, if it is not clear from the facts, then it is also necessary to establish whether the restriction on competition is ancillary to some core purpose of the agreement that may be procompetitive. ${ }^{7}$ According to Miles a restraint is ancillary if:

"(1) it is related to and implemented in connection with a venture that itself is likely to generate significant procompetitive effects through significant partial economic integration;

(2) it significantly promotes the venture's achievement of those effects, and

(3) there is no obvious method for promoting those effects that would have a significantly less restrictive effect on competition" (Miles, 1997: 66).

Where an agreement is found to be ancillary to achieving the joint venture benefit it does not automatically mean that the agreement is legal. The agreement will be analysed to see if there are any pro-competitive effects arising from it.

\section{3}

\section{Reflection on the $A N S A C$ decisions}

Although the Ansac decisions dealt with a number of important legal issues, this article is concerned only with the extent of admissible evidence in the adjudication of alleged violations of s 4(1)(b) of the Competition Act. In essence, the Commission, the Tribunal and the CAC were all of the view that the Act is quite clear about the per se anti-competitive nature of price fixing and market division agreements. In particular, the Tribunal and the CAC held that in order to find parties in contravention of $\mathrm{s} 4(1)$ (b)(i) or $\mathrm{s}$ 4(1)(b)(ii) no more evidence is required other than the facts necessary to establish that an agreement to fix prices or divide markets had indeed taken place.

Once established, no further evidence would be admissible as such agreements are prohibited per se, thus ruling out the need to consider any other justification. In this regard the Tribunal and the CAC relied on the clear distinction, explicitly written into the legislation, between the general undefined restrictive horizontal practice in $\mathrm{s} 4(1)(\mathrm{a})$, prohibited only on the basis of proof of harm to competition and allowing an efficiency defence (a "rule of reason" standard), and the specific named restrictive horizontal practices in $\mathrm{s} 4(1)$ (b) of price fixing, market division and collusive tendering, which require no further proof other than the existence of the agreement or concerted practice and which allow no justification (a per se rule) $)^{8}$.

However, in its appeals, Ansac introduced a legal complexity that had vexed courts in the United States for years. The Sherman Act does not explicitly distinguish per se conduct from conduct to which a rule of reason standard should be applied. In fact, read literally, the Sherman Act appears to prohibit all restrictions or restraints on trade regardless of their form. As even the most benign commercial contracts involve some form of restraint, a blanket prohibition would obviously be absurd. The courts were thus obliged to develop these distinctions through judicial interpretation. This development of the law by judicial interpretation has not been a smooth process and has involved considerable difficulties of semantics and legal interpretation. In particular, the process of properly characterising what constitutes per se prohibited conduct has been fraught with difficulties (Calkins, 2000: 67).

It may well be the case that section 4 of the South African Competition Act has been constructed with these distinctions included in order to specifically avoid such difficulties. However, although section 4 of the South African Competition Act is more concise than the United States' Sherman Act $^{9}$, the legal complexity around properly characterising conduct as per se prohibited appears not to have been avoided. 
In its appeal to the Supreme Court (Supreme Court of Appeal of South Africa 2005, para 38), Ansac argued that the Tribunal had erred in not admitting evidence relevant to "characterise" the conduct in order to determine whether or not it fell within the ambit of s 4(1)(b). The SCA found that the Tribunal had erred in not construing the scope of the legislative prohibition in s 4(1)(b) and thus had erred in not admitting evidence relating to the "nature, purpose, and effect" of the Ansac agreement (SCA 2005: para 40, 43, 69, 47, 65).

As a consequence of this ruling the Tribunal is now required to explicitly construe the scope of s 4(1)(b) in order to establish to what extent evidence may be admissible to determine whether the character of the agreement is such that it does (or does not) fall within the legislative prohibition in s 4(1)(b). The SCA noted further in this regard that "it is for the Tribunal to consider, in the manner and in accordance with such procedure as it may decide..." (SCA, 2005, para 60). As of the writing of this article the Tribunal has yet to make this determination.

\section{4 \\ Rationale for the per se rule}

In dealing with conduct like price fixing or market division, competition enforcement agencies generally pay little attention to whether or not the offending parties have market power. It is the act of price fixing itself that is prohibited, regardless of its actual effect. This reflects a view that price fixing by competitors does not have any evident benefit and is potentially so harmful that it should be considered unacceptable and unlawful behaviour by any firm or grouping of firms. According to Pitofsky, "Per se rules are adopted when experience has revealed that certain conduct almost always results in serious anticompetitive consequences, and is almost never justified for business reasons" (Pitofsky, 1983: 1487, 1489). In this view, agreements between competitors to fix prices (and certain other forms of market fixing) should not be tolerated because, were this behaviour to become pervasive, the mechanism by which markets are believed to deliver benefits and ultimately prosperity to consumers would crumble.
In the language that has developed in United States Antitrust law, restrictions like price fixing and market division are deemed to be per se illegal $^{10}$.

In Northern Pacific Railway v United States the Supreme Court provided the ideal rationale for per se:

...there are certain agreements or practices which because of their pernicious effect on competition and lack of any redeeming virtue are conclusively presumed to be unreasonable and therefore illegal without elaborate inquiry as to the precise harm they have caused or the business excuse for their use. This principle of per se unreasonableness not only makes the type of restraints which are proscribed by the Sherman Act more certain to the benefit of everyone concerned, but it also avoids the necessity for an incredibly complicated and prolonged economic investigation, in an effort to determine at whether a particular restraint has been unreasonablean inquiry so often wholly fruitless when undertaken. ${ }^{11}$

The per se rule exists for the reasons stated above but also because it reduces administrative costs and is a convenient means to maximise deterrence (Hylton, 2003: 122). According to Pitofsky (1983): "Per se rules represent a recognition that (1) antitrust trials, absent a per se approach are long, expensive, and complex, (2) efficient enforcement of the antitrust laws is a justifiable policy goal, and (3) there is a virtue in telling businessmen accurately and precisely the location of legal limits on business conduct".

In this regard, the enforcement of laws against cartels can be compared to the enforcement of laws against speeding. As noted by George Stigler:

Economic policy must be contrived with a view to the typical rather than the exceptional, just as all other policies are contrived. That some drivers can safely proceed at eighty miles per hour is no objection to a maximum-speed law (Stigler, 1952, page 1). 
This view is also expressed in Arizona v Maricopa County Medical Society, where the court noted:

For the sake of business certainty and litigation efficiency we have tolerated the invalidation of some agreements that a fullblown inquiry might have proved to be reasonable ${ }^{13}$.

The Court in Arizona also indicated that agreements should first be characterised to determine whether they fall into the per se category or whether wider analysis under rule of reason should be undertaken.

In Broadcast Music Inc v Columbia Broadcasting System $(B M I)^{14}$, the Court had to determine whether the issuing of a blanket licence constituted a per se violation of the Sherman Act. The Court steered its reasoning toward the rule of reason approach and found that there was no violation with such arrangement as it was necessary to implement such a blanket licence to ensure the maintenance of the copyright laws which protect the composers of music.

Many have criticised the $B M I$ ruling. Hovenkamp (1999: 211) indicated that this case may be "sui generis" and that it was not clear whether the $B M I$ case involved price fixing by 'competitors' because there was no indication whether one song competed with another and that they competed in the same market. Hylton also criticised the decision stating: "if every cartel could rely on the BMI exception, there would be nothing left to the per-se rule" (Hylton, 2003: 122).

In the Indiana Dentists case a group of dentists decided to collectively withhold X-Rays from a medical insurance company who purchased dental services on behalf of its insured clients ${ }^{15}$. The Court held that:

[a] concerted and effective effort to withhold (or make more costly) information desired by consumers for the purposes of determining whether a particular purchase is cost justified is likely enough to disrupt the proper function of the price-setting mechanism of the market that it may be condemned even absent [of] proof that it resulted in higher prices.

The Court applied the rule of reason analysis and held that it was not necessary to conduct a market definition analysis. It was clear that the agreement had anticompetitive effects and was thus condemned illegal ${ }^{16}$. The Court's approach in this case seems closer to a per se analysis, yet introduces elements of a rule of reason analysis.

In Vogel v American Society of Appraisers $(\text { Vogel })^{19}$ the court questioned the associations rule which barred fees as a percentage of appraisals. The Court cited BMI and went on to apply the per se rule against the price fixing agreement and held that "we should take a quick look to see whether it has clear anticompetitive consequences and lacks any redeeming competitive virtues" (Vogel: 603). The 'quick look' is a preliminary enquiry to determine whether the per se rule should apply.

These cases illustrate that in the United States there is no clear cut answer, perhaps even confusion, when it comes to applying the per se standard. Courts have taken very different approaches, depending on the facts of each case, as to whether the per se or rule of reason should be applied. Hovenkamp (1999: 253) aptly states that: "because per se rules are empirical judgments, their fate is to go through a continual evolutionary process".

In order unravel this apparent dilemma one must examine the rationale for having a per se standard in the first place and examine what distinguishes it from a rule of reason standard.

According to Whinston (2006: 18-19), the justification of the per se rule as an administratively convenient means to achieve maximum deterrence is an application of the theory of optimal statistical decision making to the design of optimal legal rules. On this basis Whinston argues that simply because a particular practice could in theory raise or lower welfare does not mean that it should be accorded a rule of reason standard in practice.

The difference between a "per se" and a "rule of reason" standard depends on how much evidence we require before we can decide on an agreement (Hovenkamp, 1999: 251). A rule of reason standard requires detailed analysis of market power and its effects, as well as the consideration of possible efficiency gains. As a consequence, cases that apply the rule of reason 
are likely to be lengthy and costly affairs. If every price fixing case were to be handled in this way effective deterrence would be severely hampered. In addition to the administrative cost burden the rule of reason standard tends also to favour defendants as it allows for sophisticated economic arguments to be submitted on market power and its effects.

As noted by Stephen Calkins:

Any plaintiff filing a "full blown" rule of reason case faces the prospect of long, expensive discovery, extensive motions practice, and then a merger like battle over market power without the benefit of the prophylactic language of [the] Clayton Act Section 7. Making a decision turn on a full, formal proof of market power, the Antitrust equivalent of the Full Monty, is a defendants' paradise (Calkins, 2000: 521).

Therefore, in order for the law to be effectively enforced, a distinction is made between conduct which has been identified as almost always harmful and conduct which is potentially harmful.

Price fixing, division of markets and bid rigging are almost always harmful. A statistically optimal rule prohibiting such conduct would thus be one that does not permit any justification. As soon as the door is opened to allow defence of such conduct, then the balance of convenience swings in favour of the defendants, an outcome which would undermine any public policy to break down cartels and cartel-like behaviour. By contrast, horizontal arrangements like joint ventures are only potentially harmful insofar as they involve agreement between competitors. However, such joint ventures, upon closer examination, may prove to be beneficial.

\section{5}

\section{Deconstructing section ${ }^{4}$}

It appears that the construction of the legal rule against restrictive horizontal practices in the South African Competition Act is based on a similar premise to that discussed above, namely, it provides for a statistically optimal rule to maximise deterrence of the hard core cartel conduct of price fixing, division of markets and bid rigging.

In the United States the distinction between conduct which must be accorded a per se standard and conduct which must be accorded a rule of reason standard has developed by judicial interpretation. As indicated by the Court in the National Collegiate Athletic Association $v$ University of Oklahoma (NCAA) case "there is often no bright light separating per se from rule of reason analysis. Per se rules may require considerable inquiry into market conditions before the evidence justifies a presumption of anticompetitive conduct." ${ }^{20}$ In South Africa, however, this distinction has been written into the legislation.

Section 4(1) of the Competition Act is divided into two distinct parts. S 4(1)(a) refers to:

an agreement or concerted practice between parties in a horizontal relationship that is prohibited if "it has the effect of substantially preventing, or lessening, competition in a market, unless a party to the agreement, concerted practice, or decision can prove that any technological, efficiency or other pro-competitive gain resulting from it outweighs that effect.

The wording in s 4(1)(a) is clearly akin to a rule of reason standard as it requires proof of harm to competition and allows defence on the basis of efficiency and pro-competitive gains. S 4(1)(b), on the other hand, sets out three types of restrictive horizontal practices which are prohibited outright and require no proof of harm to competition and allow no defence on the basis of technological, efficiency or procompetitive gains:

(i) directly or indirectly fixing a purchase or selling price or any other trading condition;

(ii) dividing markets by allocating customers, suppliers, territories, or specific types of goods or services; or

(iii) collusive tendering.

These three restrictive horizontal practices are specifically named, without reference to their effects on competition and allowing no defence, 
because they constitute those types of cartel behaviour that are considered to be almost always harmful and should thus be prohibited per se. In its decision on Ansac, the SCA (para 37) recognised this, stating:

It is clear from its juxtaposition with $s$ 4(1)(a) that s 4(1)(b) is aimed at imposing a 'per se' prohibition: one, in other words, in which the efficiency defense expressly contemplated by sub-para (a) cannot be raised.

Therefore, it is clear from the structure and content of section 4 of the Competition Act, and the SCA agrees, that it was the intention of the legislature that a distinct per se prohibition be applied to the restrictive horizontal practices of price fixing, division of markets and collusive tendering.

Given the clear division in the structure and the concise wording, one would naturally have expected that s 4(1)(b) would allow for a robust application of the per se rule, with little need for courts to engage in judicial interpretation. However, the experience with the Ansac cases shows that in law matters are rarely that simple. The ruling of the SCA regarding Ansac has identified a legal complexity regarding the scope of s 4(1)(b), which the Tribunal is now required to clarify. It is to this ruling we now turn our attention.

\section{6}

\section{The supreme court of appeal ruling on $A N S A C$}

In its decision the Supreme Court (para 61) agreed with the Tribunal that conduct falling within the scope of $s$ 4(1)(b) cannot not be justified on the basis of any further evidence relating to efficiencies or pro-competitive gains. Indeed, any such further evidence would not be admissible. The SCA confirmed, as did the CAC, that this is correct and also implicitly affirmed the importance of the per se rule as a statistically optimal means to maximise deterrence:

Price-fixing is inimical to economic competition, and has no place in a sound economy. Adopting the language of anti- trust law, price-fixing is anti-competitive per se. All countries with laws protecting economic competition prohibit the practice without more (SCA, 2005: para 37).

However, the SCA was of the view that the Tribunal had misdirected its enquiry (and thus misunderstood Ansac) by focusing its attention solely on whether conduct that does fall within the ambit of s 4(1)(b) can nevertheless be justified on the basis of the criteria contemplated in s 4(1)(a). According to the Supreme Court, the Tribunal failed to recognise that the real issue was not about justifications but rather about determining whether the conduct complained of falls within the ambit of s 4(1)(b) at all.

In particular, the SCA (2005: para 41) was of the view that the Tribunal did not address itself properly to the issue of whether the Ansac agreement constitutes price-fixing as prohibited by the Act. It pointed to the fact that the Tribunal had only admitted evidence pertaining to the terms of the agreement and had thus, "perhaps inadvertently", precluded any other evidence that may have been relevant to determining whether the agreement falls within the ambit of $\mathrm{s} 4(1)(\mathrm{b})$. The SCA was of the view that in endorsing the Tribunal ruling the CAC had fallen into the same error.

Whether the Tribunal and the CAC had "erred" is in fact debatable. A close reading of the Tribunal decision reveals that it did in fact determine that the Ansac agreement falls within the ambit of s 4(1)(b). The difficulty, however, is that this determination is implicit in the Tribunal's ruling and does not follow explicitly from the Tribunal having first construed the scope of $s$ 4(1)(b).

It appears that, given the particular content and structure of s 4(1)(b), both the Tribunal and the CAC were of the view that this extra step was not required. The extra step of construing the scope of s 4(1)(b) would have implied, at least in the Tribunal's view, that a purposive interpretation of the Act is necessary. This in fact is what the Tribunal understood to be Ansac's main contention in its submissions. In responding to Ansac's submission that the scope of s 4(1)(b) must first be construed, the Tribunal argued that a purposive approach 
to statutory interpretation is only required "for circumstances in which the statute under question is ambiguous" (49/CR/Apr00: 18). The Tribunal went on to argue that there is no ambiguity in s 4(1)(b) and thus little scope for interpretation (49/CR/Apr00: 18).

The SCA (2005: 37: para 51) understood the issue somewhat differently, arguing that in South Africa, where the prohibition is decreed by legislation, it necessarily follows that one can only establish whether the form of conduct complained of falls within the ambit of the prohibition by first construing the scope of the relevant prohibition.

Although the SCA was careful to point out that the scope of the prohibition is a matter of "statutory construction", it then went on to argue that once the scope had been established a factual enquiry must then be conducted to establish the nature or character of the conduct - in order to determine whether it falls within the legislative prohibition (SCA, 2005: 35: para 47).

The SCA summarised its approach as an enquiry:

to establish whether the character of the conduct complained of coincides with the character of the prohibited conduct: and this process necessarily embodies two elements. One is the scope of the prohibition: a matter of statutory construction. The other is the nature of the conduct complained of: this is a factual enquiry. In ordinary language this can be termed 'characterising' the conduct - the term used in the United States, which Ansac has adopted (SCA, 2005: 35: para 47).

It is interesting to note that, despite its references to a factual enquiry, the SCA was unwilling to provide guidance on what that factual enquiry should entail. The SCA ultimately ruled that the Tribunal failed to expressly construe s 4(1)(b) and establish its scope, and thus could not have properly established what evidence may have been admissible - presumably because such evidence may have been necessary for the purposes of characterising the conduct.

But the SCA based this ruling on the premise that the scope of the prohibition in $\mathrm{s} 4(1)(\mathrm{b})$ is not self evident. It is here where the main difference of opinion between the SCA and the Tribunal and CAC is to be found. Clearly, the SCA, the Tribunal and the CAC agree that the scope of $s 4(1)(b)$ is a matter of statutory construction. However, the Tribunal and the CAC appear to have been of the view that the scope of $s$ 4(1)(b) is clearly set out in terms of the content of the legislative prohibition in s 4(1)(b). As the Tribunal noted in its decision:

Section 4(1)(b), on the other hand, specifically details the very content of the agreements that it seeks to proscribe these being agreements to fix price or any other trading condition, agreements to divide markets, and collusive tendering. But this is all that is specified. In plain contrast with the requirements of Section 4(1)(a), those who set themselves the task of impugning agreements described in Section 4(1)(b) do not have to establish any deleterious impact on competition (49/CR/Apr00: 17).

The SCA, however, was not convinced that the formulation set out in s 4(1)(b) sufficiently captures the scope of the prohibition, and thus concluded that the scope of the prohibition is not self evident. The SCA alluded to the possibility of a legitimate and economically beneficial joint venture consisting of competitors who necessarily set a uniform price for the purposes of selling the services or products of the venture. This obviously begs the question as to whether such a venture would be captured by the per se prohibition in s 4(1)(b)? The SCA was of the view that there is no a priori reason to assume that it should. In particular, the SCA questioned (without providing answers) whether, upon properly construing the scope of the prohibition, such an arrangement would indeed constitute prohibited price fixing as contemplated by s 4(1)(b).

The question posed here cannot easily be dismissed because it implies potential economic harm arising from an inappropriately applied per se rule. Such an outcome would surely not have been intended by the legislature or the policy makers.

From an economic point of view the character of the legitimate joint venture is quite different 
from the character of the cartel arrangement to fix prices and restrict output. However, both the legitimate joint venture and the cartel arrangement may involve competitors entering into an agreement which results in the setting of a uniform price. On a purely literal interpretation of s 4(1)(b)(i) both arrangements would be prohibited per se. However, for the good of the economy, only the cartel arrangement should be prohibited and the joint venture allowed. In this context "characterisation" makes perfect economic sense.

However, what does this mean for the application of a per se rule? The view of the $\mathrm{CAC}$, in its ruling, is clear on this issue:

Were this court to adopt the approach urged upon us by the applicants, it would in effect be blurring the distinction between per se and rule of reason and effectively render Section 4(1)(b) a form of rule of reason approach (Competition Appeal Court, 2001: 8).

The CAC went on to argue, with reference to its understanding of how characterisation works:

That however is not the way per se jurisprudence works, nor does it reflect the clear intention of the Act which adopted a clear policy choice. The policy choice it made was to highlight three separate forms of activity being price fixing, dividing up of markets and collusive tendering, which, as with much comparative competition law, are regarded as egregious activities of a kind, which competition authorities must prohibit (CAC, 2001: 8).

If experience shows that certain types of arrangements are almost always anti-competitive then the implementation of a per se rule prohibiting these types of arrangements also makes good sense from an economic policy point of view.

As noted previously in this article, the SCA clearly recognised the per se nature of s 4(1)(b), and thus implicitly acknowledged the intention of the legislature in having a statistically optimal rule to maximise deterrence. However, the SCA also found that an overly literal interpretation of s 4(1)(b) may potentially produce an outcome, in prohibiting certain types of arrangements, that would also not have been intended by the legislature. The question that must now be addressed is whether the SCA's apparent endorsement of a process of characterisation is, or can be made, consistent with the policy objective of the per se rule in s 4(1)(b), namely, to maximise deterrence of certain types of arrangements?

In order to address this issue we examine what is meant by characterisation and discuss the legal and economic rationale for it. We then examine how the notion of characterisation might best be interpreted and applied in order that it be consistent with the application of the per se standard as a statistically optimal rule to maximise deterrence.

\section{6 \\ Characterising price \\ fixing agreements: legal and economic rationale}

The decision to categorise an agreement or practice as having the same character as the practice of "fixing a purchase or selling price", 'dividing markets' or "collusive tendering", as they appear in s 4(1)(b), implies that they have been given a specific meaning which in turn confers on them a certain character.

Obviously we must be clear on what the meaning and character of the phrases describing these practices are before we attempt to categorise different agreements or practices on the basis of whether or not they have the same character.

For the purposes of this article we will focus only on the phrase describing the practice of "fixing a purchase or selling price". However, the analysis can easily be carried over to the other practices set out in s 4(1)(b).

The question, 'what do the words 'fixing a purchase or selling price' mean?" leads one to consider the Tribunal's reference to Alice's celebrated rejoinder to Humpty Dumpty:

With due respect to the learned authorities upon which Mr. Unterhalter relies, the statute is, in this instance, so devoid of ambiguity that he may have rested his case 
on Alice's celebrated rejoinder to Humpty Dumpty:

"When I use a word", Humpty Dumpty said, in a rather scornful tone, "it means just what I choose it to mean - neither more nor less."

"The question is", said Alice, "whether you can make words mean so many different things" (Carrol, 1980: 113)" (Competition Tribunal, 2001: 18. 49/CR/Apr00)

However, despite its clear structure and concise wording the section nevertheless does not permit an ordinary literal interpretation. The words "fixing a purchase or selling price" must be understood in terms of the context within which they are written in the Act and with reference to the intention of the legislature - as opposed to merely reflecting on the ordinary literal meaning of the words. The literal theory stipulates "words should be given their ordinary and grammatical or natural and ordinary meanings as the first step in the process of interpretation" (Devenish, 1992: 26). Literal theory may only be departed from if there is ambiguity or absurdity that would lead to an unjust result (Devenish, 1992: 28).

However, we submit that a more holistic approach to the literal theory should be taken. This is so evidenced by the fact of the very appearance of these types of practices in s 4(1)(b). They have clearly been singled out for special treatment because of their character as the most egregious types of anti-competitive cartel behaviour. The Court in the BMI case recognised the impact of a restrictive literal interpretation, examined the purpose and effect of the arrangement and stated that:

In characterizing this conduct under the per se rule our inquiry must focus on whether the effect and, because it tends to show effect... the purpose of the practice is to threaten the proper operation of our predominantly free market economy- that is whether the practice facially appears to be one that would always tend to restrict competition and decrease output, and in what portion of the market, or instead one designed to 'increase economic efficiency' and render markets more rather than less competitive ${ }^{21}$
Further, the wording in section 4 also imposes a certain character upon the listed practices in s 4(1)(b). Firstly, the main heading in section 4 refers to restrictive horizontal practices prohibited. ${ }^{22}$ Secondly, s 4(1)(b) refers to "any of the following restrictive horizontal practices" - thus establishing price-fixing, dividing markets, and customer allocation as a subset of restrictive horizontal practices to be prohibited in terms of the requirements set out in section 4.

It therefore follows that any practice or agreement that allegedly contravenes any of the provisions in $\mathrm{s} 4(1)$ (b) must first be properly characterised in order to determine whether the alleged practice falls within the ambit of $s$ $4(1)(b)$, that is to say, is of the same character as the character of the practices set out in $\mathrm{s}$ 4(1)(b).

\section{7}

\section{How should we characterise agreements?}

"All analytical approaches begin with an initial characterisation of an agreement" (Correia, 1998: 737-771). Once an agreement is characterised as "price fixing" it is per se illegal. The question is, how do we determine the method of characterising an agreement? This is a sophisticated economic and legal question and it is important to outline the periphery of this issue.

Although the SCA has ruled that characterisation must feature in the Tribunal's adjudication of these matters, it is not at all clear what the appropriate method for characterisation should be. The SCA noted that it was not within in its mandate to construe the scope of s 4(1)(b) and thus determine what evidence is admissible. This is left to the Tribunal to consider, "in the manner and in accordance with such procedure as it may decide" (SCA, 2005: 43: para 60).

In this regard, the Tribunal is faced with a difficult task: it must decide an appropriate method to "characterise" the conduct complained of that is not inconsistent with the application of the per se rule. The CAC, for example, could not see how characterisation could not blur the line between the per se and rule of reason standards. 
Be that as it may, it is of the utmost importance that whatever method of characterisation is introduced, it is constructed in such a way that the balance of convenience remains firmly in favour of the enforcing agency so as not to undermine its effectiveness in clamping down on hard core cartel conduct.

We do not presume here to be so ambitious as to propose what an appropriate method of characterisation should be in the South African context. Rather, we discuss some of the principles that might be applied. In this regard, we draw from lessons learned in the United States where the concept of characterisation was introduced and developed. Important cases which we discuss include the amicus brief in the NCAA case, the Massachusetts $v$ Board of Optometry case, and a six-step approach proposed by author Herbert Hovencamp (1999). We then analyse Beckner and Salop's (1999) principles of decision theory and show how these principles might be applied in the South African context.

In the NCAA v Board of Regents case the United States Solicitor General, with the Federal Trade Commission, filed an amicus brief in which they proposed a "truncated" rule of reason when analysing problematic price fixing agreements:

[C]ourts should first ask whether challenged conduct is likely, absent an efficiency justification ${ }^{23}$, to lead to the restriction of output, for such conduct is inherently suspect. Where output restriction does appear likely, we must ask whether there is a plausible efficiency justification for the practice, i.e., is there reason to believe that the restraint may nonetheless have significant efficiency benefits and therefore enhance competition and output. In the event that there is no plausible efficiency justification, the suspect practice is per se illegal....

But, in cases where the participants raise a plausible efficiency justification for conduct that is facially suspect, per se characterisation is inappropriate, because more scrutiny is needed to evaluate the restraint's overall competitive effect. It may be that further examination will show that the proffered efficiency justification should be rejected; in that event, the conduct can still be condemned as unreasonable without completing a 'full' rule of reason analysis that includes market definition and market power determination. On the other hand, if efficiency benefits are shown to be likely, a more elaborate rule of reason inquiry is called for, with a thorough analysis of market power, in order to determine whether the practice is, on balance, harmful or beneficial. ${ }^{24}$

This method of characterisation has similar elements to that proposed in Massachusetts $v$ Board of Optometry:

First we asked whether the restraint is 'inherently suspect'. In other words, is the practice the kind that appears likely, absent an efficiency justification, to 'restrict competition and decrease output?' For example, horizontal price fixing and market division are inherently suspect because they are likely to raise price by reducing output. If the restraint is not inherently suspect, then the traditional rule of reason, with attendant issues of market definition and power, must be employed. But if it is inherently suspect, we must pose a second question: Is there a plausible efficiency justification for the practice?... Such an efficiency defense is plausible if it cannot be rejected without extensive factual inquiry. If it is not plausible, then the restraint can be quickly condemned. But if the efficiency justification is plausible, further inquiry- a third inquiry- is needed to determine whether the justification is really valid. If it is, it must be assessed under the full balancing test of the rule of reason without further inquiry- there are no likely benefits to offset the threat to competition. $^{25}$

The Court in California Dental Association took an opposing view to the Mass. v Board of Optometry case above and indicated that there is a clear distinction between per se and rule of reason analysis. 
Herbert Hovenkamp (1999: 256-257) discussed how the process of characterisation can take place by providing a road map guide containing six steps. We have taken this road map and drafted a flow diagram identifying these steps.

\section{Hovenkamp's road map to characterisation}

Step 1: $\begin{gathered}\text { Does the agreement arguably threaten either to reduce output or raise price } \\ \text { in some nontrivial way? }\end{gathered}$

Step 2: Is this agreement naked or ancillary to some other joint venture or agreement that is itself plausibly efficiency creating or otherwise beneficial to consumers? An agreement is naked if it is formed with the objectively intended purpose or likely effect of increasing price or decreasing output in the short run. As a result a naked agreement is rational only on the premise that the participants have market power. By contrast, an ancillary agreement reduces cost or improves the product and can be profitable whether or not the firms have any market power.

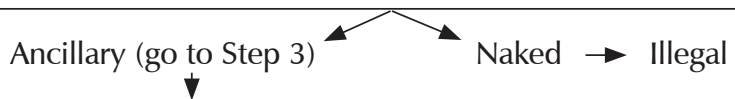

Step 3: Look at the market power held by the parties to the challenged restraint. How numerous are they? How concentrated is the market? Is there a substantial competitive market outside the venture? Are entry barriers high or low? Is the venture non exclusive - that is, are participants to the venture free to offer the covered product or service outside the restraint imposed upon the venture?

Market power ex is plausible $\rightarrow$ Legal (go to Step 4)

Step 4: Is there strong evidence that the challenged practice creates substantial efficiencies by reducing the participants's costs or improving product or service quality?

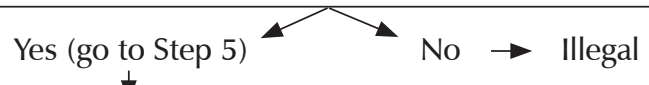

Step 5: Can the same efficiencies be achieved by reasonably available alternatives that have less potential to harm competition? If yes, the practice in its present form is illegal, although the injunctive remedy should be limited to condemning the current form or ordering the alternative.If no less restrictive alternative is available then proceed to Step 6.

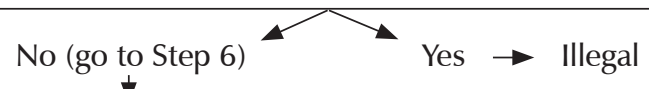

Step 6: Balancing. Hopefully, few cases require real balancing; but if a challenged restraint simultaneously produces opportunities for both anticompetitive practices and substantial efficiencies, a court must have a guide one way or the other. The best guide seems to be that if the threat to competition is real, and if the defendants cannot come up with a way of restructuring their venture so that this threat is substantially dissipated, the court's only conclusion must be to condemn the arrangement. At this point, intent and good faith may become relevant, particularly in cases where the defendants have technical expertise and their professional judgment must have a certain amount of deference if their market is to function properly. Nevertheless, any court faced with the prospect of balancing must go back to step 5 and look hard for workable less restrictive alternatives. 
In the Arizona v Maricopa County Medical Society ${ }^{26}$ case, the Supreme Court applied the per se rule to an agreement by physicians who sold their services at a maximum fee. Hovenkamp (1999: 261) suggests that the court was wrong to apply the per se rule as it failed to analysis some additional evidence mentioned in its opinion. Using his "road map" guideline above he states that:

Under the road map given above, the Maricopa joint venture at least arguably threatens to raise prices or reduce output, if we accept the claim that maximum price fixing can be disguised minimum price fixing. It flunks step 1 . Step 2 required much more analysis than the Supreme Court was willing to give. The Maricopa agreement was a joint venture producing transactional efficiencies- in this instance, reducing customer search costs for a variety of medical services. Effectively, the Maricopa health consumer was given a list that said 'the doctors on the enclosed list have agreed to charge no more than the stated prices for the enclosed list of services.' At that point the customer could still make a choice between buying inside the venture or buying outside. The Supreme Court was wrong to end the inquiry at step 1 (Hovenkamp, 1999: 261).

In a South African context, courts should use caution when using Hovenkamp's road map to characterise agreements. Under s 4(1)(b) the analysis would probably stop at Step 3, with a distinction between naked and ancillary agreements. It would be perilous to go the route of a market analysis, as this leads to a rule of reason approach, which would be inconsistent with the structure in $\mathrm{s} 4(1)$.

Earlier in this article we noted that the rationale for a per se standard is that it functions as a statistically optimal rule to maximise deterrence. The idea of a statistically optimal rule is drawn from the application of decision theory to the design of optimal legal rules (Whinston, 2006: 18-19). In considering the development of an appropriate method of characterisation it might also be instructive to apply the principles of decision theory.
In this regard we draw largely on the work of Beckner and Salop (1999: 41-57) in their article on decision theory and antitrust rules. Beckner and Salop note that judicial decisions must necessarily take into account that information is imperfect and costly to gather and process. In general terms, the court will want to minimise the expected consumer welfare cost of making a false decision. In making its decision the court must consider the cost, in consumer welfare terms, of erroneously prohibiting the conduct (a false negative) as well as the cost of erroneously approving the conduct (a false positive) and weigh these up against the net consumer welfare benefit arising from the conduct in question. In the case of collusive price fixing the cost to consumers is likely to be quite high and the benefit low or non-existent. In such a case the court will want to minimise the cost of a false positive finding (Beckner \& Salop, 1999: 49-51).

So far we have analysed the decision process as if it were applied only with regard to the specific facts of a single case. The reality, however, is that cases make precedent and thus have implications in the broader regulatory environment. It is for this reason that legal rules are designed on the basis of statistically optimal outcomes. In particular, the judicial decision must consider the issue of optimal deterrence. According to Beckner and Salop (1999: 51)

Over deterrence might involve deterring welfare enhancing cooperation or innovation by firms that fear a finding of liability even when their conduct does not reduce consumer welfare. Under deterrence might involve firms being overly aggressive in the expectation that their conduct might escape punishment. Concerns about optimal deterrence may lead courts to shade the standard in one or the other direction to take into account differences in the cost of false convictions versus false acquittals.

In addition to minimising the cost of false decisions and applying statistically optimal rules, courts will also want to reduce the costs of information gathering and processing. This implies a rationalisation which pays attention to the level of information necessary to avoid 
the false decisions, and the sequence in which different types of information are gathered and processed. The important point to note is that information is costly to gather and imperfect information may result in false decisions. Courts must weigh the expected benefits of additional information against the cost of gathering and processing the additional information. If, on the basis of the limited information available to it, there is a strong presumption on the part of the court that the alleged anticompetitive conduct will result in net consumer harm, then there is a strong justification to make a decision on the basis of the limited information available - rather than incurring additional costs in gathering and processing further information (Beckner \& Salop, 1999: 52).

If one applies the above reasoning to the South African context it could be argued that the per se rule (implied in the structure of $s$ $4(1)$ ) is designed to prevent potentially harmful underdeterrence, whereas the requirement to 'characterise' (implied in the ruling of the SCA) is meant to prevent potentially harmful overdeterrence. Most importantly, however, the per se standard, as a distinct feature of the structure of $s 4(1)$, appears designed to place a strict limit on the amount of information that should be considered by the court in deciding cases involving allegations of the anticompetitive practices set out in $\mathrm{s} 4(1)$.

But is it possible to reconcile the per se objective, which places a limit on information gathering and processing, with the objective of characterisation, which requires at least some level of information? We suggest that this can be done if the judicial decision process of the court is placed firmly within a decision theoretic framework. Further, a rigorous application of decision theoretic principles should allow the court sufficient discretion (not easily challenged on appeal!) to restrict the extent of information gathering and processing required for characterisation so as to preserve the robustness of the per se standard as a means to maximise deterrence of hardcore cartel conduct.

Beckner and Salop (1999: 53) elaborate on the application of decision theory with reference to a multistage decision making process. The multistage decision process is based on the understanding that the decision maker faces costs in gathering and processing information and that imperfect information may lead to erroneous determinations. It also recognises that decisions have to be made regarding the extent of information costs and the priority accorded to gathering different types of information relevant to presumptions about particular outcomes. In particular, it is assumed that the courts hold certain presumptions about the expected benefits and harms arising from particular classes of activities.

Beckner and Salop identify seven steps in the multistage decision making process. We summarise these with reference to the decision tree in Annex 1. Our purpose here is not to provide a detailed analysis of each stage of the decision process, but rather to identify some features of a general decision making framework that a court could apply when adjudicating on an alleged contravention of s 4(1)(b) of the Competition Act. We have identified the relevant stages below ${ }^{27}$ :

\section{Stage 1. Initial characterisation}

In this stage the court gathers information but does not make any decision. Beckner and Salop note that the information considered at this stage would be of a limited nature but sufficient to allow the court to form its initial presumptions about the case. According to Beckner and Salop this initial characterisation could be based on the specific facts of the case as well as the courts experience and knowledge regarding a broader class of cases (Beckner \& Salop, 1999: 56-58).

The SCA ruling referred to evidence relating to the nature, purpose and effect of the agreement that must be considered in determining whether the agreement falls within the scope of s 4(1)(b). While the nature and purpose of the alleged conduct may be more or less self-evident on the basis of basic low cost information, the same cannot easily be said about the effect of the agreement. The danger in allowing evidence on effects is that it could allow "front loading" (Beckner \& Salop, 1999: 58) by defendants of costly fact gathering at the initial stage and thus, as the CAC had feared, blurring the line between the per se and rule of reason standard. 
But rule of reason analysis at this stage is not in line with decision theoretic principles as it would not allow the court to first make an informed decision on whether the benefit from engaging in further cost based information gathering would be justified given the expected consumer harm arising from the complained of conduct.

Despite the unfortunate use of the word "effect" by the SCA, the per se standard may nevertheless be rescued by the fact that the court is not constrained, when conducting an initial characterisation, from having reference to general experience and knowledge about a broader class of cases. In terms of s 4(1)(b) this "broader class" of cases is clearly stated in the legislation, namely fixing a purchase or selling price, dividing markets and customer allocation. Once initial characterisation places the complained of conduct within this "broader class" of cases, the "effect" of such conduct is surely evident with reference to generally available experience and knowledge about the class of conduct and which will not be specific to the facts of the individual case. If it transpires that the Tribunal is required to admit some form of evidence on effects then this should be limited to only low cost information that clearly contradicts the general experience and knowledge about the broader class of conduct. The Tribunal may take judicial notice of certain legal, social and economic aspects of the society in which such laws operate (Driedger, 1983: 150).

\section{Stage 2. Summary disposition based on initial characterisation}

At this stage the court could make a decision about the case. Such a decision would be based on the initial characterisation of the case. If the court were to make a decision in favour of the plaintiff it would probably be because the court had formed a presumption that the complained of conduct is of such a nature that it should be prohibited per se (Driedger, 1983: 57).

There is no reason to believe, in the context of s 4(1)(b), that making a decision at this stage would be inconsistent with the SCA ruling. The important point is that the decision is based on an initial characterisation which necessarily involves construing the scope of s (1)(b) and conducting a limited fact-based inquiry.

\section{Stage 3. Re-characterisation}

If, in the previous stages, the court found that it was not able to make a decision on the basis of available information, it may then gather additional low-cost information (Driedger, 1983: 57).

If there is uncertainty regarding evidence of the purpose of the alleged conduct then the Tribunal may admit further low-cost information at this stage. It is still important that "front loading" of costly information not be permitted at this stage. The purpose here is simply to supplement and refine the initial characterisation. The extra step may be necessary in more complicated cases where an initial characterisation may not be straight forward.

\section{Stage 4. Summary disposition based on stage 3 re-characterisation}

As with stage 2, the court may make a decision on the basis of the information gathered in stage 3 and, this time, on the basis of a slightly more informed presumption.

We note here that progression of decision making to any further stages would bring us into the territory of rule of reason analysis. In the $\mathrm{s}$ 4(1)(b) context this would imply that a decision had been made that the alleged conduct does not fall within the ambit of s 4(1)(b) but should either be decided in favour of the defendant or (more likely) be evaluated under s 4(1)(a), which would have to be adjudicated according to a rule of reason standard. The Tribunal would then go back to the start and progress through all the decision stages right the way through to the final stage.

In conclusion, any argument suggesting that the SCA ruling implies that the judicial determinations of the Tribunal should proceed beyond stage four in the multistage decision process (to stages which require the consideration of more "costly" information) would introduce a method of characterisation that would be completely incompatible with the maintenance of the per se standard as envisaged 
in the Competition Act. This would imply a fundamental inconsistency in the SCA ruling, as the SCA had explicitly confirmed the per se standard inherent in the structure of section $4(1)$ and the content of 4(1)(b). Finally, it would seriously undermine the public policy objective of a statistically optimal rule to maximise deterrence of hardcore cartel behaviour.

\section{8}

\section{Conclusion}

In this article we have shown that the structure and content of s 4(1)(b) does not rule out some method of characterising conduct in order to determine whether it falls within the scope of s 4(1)(b). We have examined the legal and economic rationale for this and established that an appropriate method of characterisation is not inconsistent with maintaining a per se standard for the adjudication of conduct falling within the ambit of s 4(1)(b) of the Act.

However, it is recognised that without a clear framework for determining an appropriate method of characterisation there is a very real risk of a blurring of the line between per se and rule of reason. This would have dire implications, as it would open the door for "front loading" of costly information by defendants and thus seriously undermine the effectiveness of the per se standard.

In order to overcome this problem we suggest a framework based on the rigorous application of decision theoretic principles. This should allow the Tribunal sufficient discretion (hopefully not easily challenged on appeal!) to restrict the extent of information gathering and processing required for characterisation so as to preserve the robustness of the per se standard as a means to maximise deterrence of hardcore cartel conduct.

\section{Endnotes}

1 American Natural Soda Ash Cov The Competition Commission, Botswana Ash Company and others case no 554/03.

2 American Natural Soda Ash Corp et al v the Competition Commission, Botswana Ash (Pty) Ltd et al Competition Appeal Court Case Number 12/CAC/Dec01.
3 "The word cartel came into English in the $16^{\text {th }}$ century from the old Italian word cartello, which meant a note or letter of defiance, a preliminary step in the etiquette of dueling. A cartel in this sense is now obsolete. A second meaning of cartel that slipped into the language a little later (and is still in use) is a written agreement between opposing armies for the exchange of prisoners. This meaning was extended by German writers in the 1880 s to describe a government coalition that brought together normally antagonistic political parties. Shortly thereafter the word kartell was applied to a combination of two or [more] business rivals for the purpose of regulating prices or output of an industry. The word cartel was first used in English in 1902 in this business sense in three British publications to refer to what were formerly called "producers syndicates" or "trusts" in the sugar and steel industries." 'Oxford English Dictionary in John Conner (2001: 20) GSlobal Price Fixing: Our customers are the enemy, Kluwer Academic Publishers: Boston.

4 Broadcast Music v CBS 441 US 1 (1979) 19-20.

5 See ABA Section of Antitrust Law in Angland, J, chair [et al.] (1997) Antitrust Law Developments (4th $e d$.$) American Bar Association: Chicago,$ Illinois, (pg. 398), in Gregory J Werden 'Antitrust Analysis of Joint Ventures: An Overview' (1999).

6 See Copperweld Corp v Independence Tube Corp 467 US 752, 768 (1984).

7 See NFL v North Am. Soccer League 459 US 1074, 1079 (1982) and SCFC ILC, Inc v Visa USA, Inc 36 F 3d 958, 970 (10 ${ }^{\text {th }}$ Cir 1994).

8 See American Natural Soda Ash Corp et al $v$ the Competition Commission, Botswana Ash (Pty) Ltd et al. Competition Tribunal case number 49/CR/ Apr00 and 12/CAC/Dec01.

9 Section 1 Sherman Act 15 US 1890: "Every contract, combination in the form of trust or otherwise, or conspiracy, in restraint of trade or commerce among the several States, or with foreign nations, is declared to be illegal. Every person who shall make any contract or engage in any combination or conspiracy hereby declared illegal shall be deemed guilty of a felony, and on conviction thereof, shall be punished..."

10 In United States $v$ Socony-Vacuum Oil Co 310 US 150 (1940), the Court held that all price fixing by firms competing in an open market is per se unlawful.

11356 US 1 (1958) 5.

12 Also consider, Bork, RH "Fixing the price fixing confusion: A rule of reason approach" (1983) Yale Law Journal, 9: 706-709. in K.N. Hylton (2003) 
Antitrust law: Economic Theory and Common Law Evolution, (pg. 122), Cambridge University Press: New York.

13457 US (1982) 332, 334.

14441 US (1979) 1.

15 FTC v Indiana Federation of Dentists, 476 US 447, 106 S Ct 2009 (1986).

16 Ibid at 457, $106 \mathrm{~S} \mathrm{Ct}$ at 2017.

17 California Dental Association v FTC US 119 S Ct 1604 (1999).

$18744 \mathrm{~F} 2 \mathrm{~d} 598$ ( $7^{\text {th }}$ Cir 1984).

19 National Collegiate Athletic Association v University of Oklahoma 468 US 85 (1984) 104.

20441 US 1(1979) 19-20.

21 In Chotabhai v Union Government (Minister of Justice) and Registrar of Asiatics1911 AD 13 at 24, C.J. De Villiers expressed the traditional literal viewpoint in this regard by stating that "the headings of different portions of a Statute may be referred to for the purpose of determining the sense of any doubtful expression in a section ranged under any particular heading".

J. Didcott, in $S v$ Liberty Shipping and Forwarding (Pty) Ltd and others 1982 (4) SA (D) 285-6, observed that: "The headings to a section may be brought into account ... to resolve an ambiguity or doubt raised by the text..."

22 An efficiency justification exists if the challenged restraint increases the quantity or quality, or reduces the cost, of overall output - e.g., by creating a new product, improving the operation of a market, or reducing production or marketing costs - and is reasonably necessary to achieve such efficiencies (Calkins 2000: 523).

23 Brief for the United States as Amicus Curiae, NCAA v Board of Regents in Calkins (2000: 523).

24110 FTC 549 (1988) 604.

25457 US 332, 102 S Ct 2466 (1982).

26 Beckner and Salop (1999: 57) list a few other stages which we do not find relevant for the purposes of this article but are as follows: Stage 5: Sequencing and More Complete Information Gathering on First Issue;

Stage 6: Subsequent Summary Disposition Based on Partial Information or More Complete Information Gathering on Second Issue; and

Stage 7: Full Merits Determination.

\section{References}

1 BECKNER, C.F. \& SALOP, S.C. (1999) "Decision theory and antitrust rules," Antitrust Law Journal, 67(1): $41-67$.
2 CALKINS, S. (2000) "California Dental Association: Not a quick look but not the full Monty," Antitrust Law Journal, 67: 495-557.

3 COMPETITION APPEAL COURT (2001) American Natural Soda Ash Corp et al. $v$ the Competition Commission, Botswana Ash (Pty) Ltd et al., Competition Appeal Court Case Number 12/CAC/Dec01.

4 COMPETITION TRIBUNAL (2000 and 2001) American Natural Soda Ash Corp et al. v the Competition Commission, Botswana Ash (Pty) Ltd et al., Competition Tribunal case number 49/CR/ Apr00 and 12/CAC/Dec01.

5 CORREIA, E. (1998) "Joint ventures: Issues in enforcement policy" Antitrust Law Journal, 66: 737771.

6 DEVENISH, G.E. (1992) Interpretation of Statutes, Juta: Cape Town.

7 DRIEDGER, E.A. (1983) "Construction of statutes: 150" in Devenish, G.E. (1992) Interpretation of Statutes (pg. 118), Butterworths: Toronto.

8 FOX, E.M. (2002) Cases and Materials on the Competition Law of the European Union, Thomson West: St Paul, Minnesota.

9 HOVENKAMP, H. (1999) Federal Antitrust Policy: The Law of Competition and its Practice ( $2^{\text {nd }}$ ed.) West Publishing Company: St Paul, Minnesota.

10 HYLTON K.N. (2003) Antitrust Law: Economic Theory and Common Law Evolution, Cambridge University Press: New York.

11 MILES, J.J. (1997) "Joint venture analysis and provider controlled health care networks," Antitrust Law Journal, 66: 127-166.

12 PITOFSKY, R. (1983) “Commentary: In defense of discounters: The no frills for a per se rule against vertical price fixing," Geo $L J, 71: 1487$, 1489.

13 STIGLER, G.J. (1952) "The case against big business", Fortune Magazine May 1952 in Michael D. Whinston (2006) Lectures in Antitrust Economics, (pg. 18), The MIT Press: Cambridge Massachusetts.

14 SUPREME COURT OF APPEAL (2005) American Natural Soda Ash Co v The Competition Commission, Botswana Ash Company and others case no 554/03.

15 WERDEN, G.J. (1999) 'Antitrust analysis of joint ventures: An overview', Antitrust Law Journal 66: 701-755.

16 WHINSTON (2006) Lectures in Antitrust Economics, The MIT Press: Cambridge Massachusetts. 